\title{
ТРОМБОФІЛІЯ, УСКЛАДНЕНА РЕЦИДИВУЮЧОЮ ТРОМБОЕМБОЛІЄЮ ЛЕГЕНЕВОЇ АРТЕРІЇ - КЛІНІЧНИЙ ВИПАДОК ІЗ АНАЛІЗОМ СУЧАСНИХ ДІАГНОСТИЧНО- ЛІКУВАЛЬНИХ АЛГОРИТМІВ ВЕДЕННЯ ХВОРИХ
}

\author{
๑М. І. Швед, Н. М. Ковбаса, С. М. Геряк, С. Й. Липовецька, \\ Л. В. Левицька, О. А. Прокопович, О. Л. Сидоренко
}

ДВНЗ «Тернопільський державний медичний університет імені І. Я. Горбачевського МОЗ України»

РЕзЮМЕ. Венозний тромбоз і емболія (ВТЕ) - одне з найтяжчих за перебігом і загрозливих для життя ускладнень.

Мета дослідження - проаналізувати сучасні підходи до діаґностики і лікування хворих із тромбофілією, ускладненою рецидивуючою тромбоемболією легеневої артерії, на основі власного клінічного випадку.

Результати. Для оцінки ризику ВТЕ у госпіталізованих пацієнтів терапевтичного профілю доцільно використовувати шкалу Падуа, а при повторних ВТЕ/ТЕЛА, особливо у пацієнтів молодого віку, показане обов'язкове обстеження з метою підтвердження/виключення вродженої або набутої тромбофілії, що визначає програму профілактики повторних ВТЕ. У хворих з діагностованою тромбофілією необхідно використовувати персоніфікований підхід до вибору антикоагулянтних засобів профілактики. Показання для застосування прямих чи непрямих антикоагулянтних засобів визначаються наявністю у пацієнта певної форми тромбофілії. Лише використання такого діагностичного алгоритму дозволяє своєчасно призначити таким пацієнтам адекватну профілактичну антикоагулянтну терапію, що підтверджує описаний нами клінічний випадок.

Висновок. Велика частота захворюваності на ВТЕ, недостатні знання практикуючих лікарів щодо діагностики самої хвороби, визначення її причин і клінічних форм, а також неоднозначність отриманих результатів різних програм лікування іпрофілактики ВТЕ/ТЕЛА обґрунтовують необхідністьпроведення додаткових багатоцентрових клінічних досліджень та більш широкого обговорення даної проблеми в лікарському середовищі.

КлючовІ слОВА: тромбоемболія легеневої артерії; тромбофілія; діагностика; лікування.

Вступ. Венозний тромбоз і емболія (ВТЕ) одне з найтяжчих за перебігом і загрозливих для життя ускладнень у клінічній медицині. Щорічна захворюваність на ВТЕ серед населення європейських країн та США становить 104 - 183 випадки на 100 тис. людино-років (Not. Rev. Cardiol., 2015). В Україні щорічно реєструється близько 64 тисяч Хворих на ВТЕ [8]. В зв'язку з тим, що виникнення ВТЕ пов'язано з високим ризиком смерті, питання своєчасної діагностики і адекватної профілактики цих ускладнень стають надзвичайно актуальними.

Мета дослідження - аналіз сучасних підходів до діагностики і лікування хворих із тромбофілією, ускладненою рецидивуючою тромбоемболією легеневої артерії, та розбір клінічного випадку із власної практики.

Основна частина. Понад 160 років тому Р. Biрхов визначив тріаду факторів, що спричиняють виникнення венозного тромбозу: підвищена здатність крові до згортання, сповільнення току крові у вені, пошкодження ендотелію судини. 3 того часу медична наука зробила великий крок у розв'язанні проблем венозного тромбозу та емболії: встановлена наявність окремих видів вроджених тромбофілій, визначені деякі чинники і фактори ризику набутих тромбофілій, впроваджені в клінічну практику непрямі антикоагулянти, нефрак- ціонований та низькомолекулярні гепарини, тромболітичні засоби, опрацьовано техніки і методики операцій тромбемболектомії, встановлення кава-фільтрів тощо. Проте щороку у країнах Європи та США від венозного тромбозу та емболії легеневої артерії помирають майже 500 тисяч хворих.

На особливу увагу заслуговують виявлення i корекція факторів ризику венозних тромбоемболій серед різних контингентів терапевтичних пацієнтів. Щоб досягти певного успіху у вирішенні цього завдання, на нашу думку, необхідно підвищити рівень знань лікарів загальної практики 3 проблеми ВТЕ та їх настороженості щодо можливості розвитку ВТЕ у певної категорії хворих. 3 метою стратифікації ризику ВТЕ у пацієнтів хірургічного профілю рекомендується використовувати шкалу (Caprini) Капріні, а для оцінки ризику ВТЕ у пацієнтів терапевтичного (нехірургічного) профілю - шкалу (Padua) Падуа (табл. 1).

Згідно з цією шкалою, високий ризик розвитку ВТЕ мають пацієнти, у яких сума балів $\geq 4$.

Принагідно зауважимо, що набір пацієнтом понад 4 балів за шкалою Падуа свідчить про високий ризик ВТЕ і доцільність призначення медикаментозної (дезагрегантної та антикоагулянтної) профілактики ТЕЛА. Клінічна ситуація може суттєво погіршуватись у пацієнтів з наявністю генетич- 
Огляди літератури, оригінальні дослідження, погляд на проблему, ювілеї ної схильності (у 25 \% випадків) до тромбофілії або з наявністю провокуючих факторів: автоімунна та інфекційно-імунна тромбофілія, паранеопластич-

на та метаболічна (при гіперглікемії, гіперліпідемії, гіпергомоцистеїнемії) форми, а також ятрогенні, в тому числі медикаментозні форми тромбофілії.

Таблиця 1. Шкала Падуа для оцінки ризику ВТЕ (ТЕЛА) у госпіталізованих хворих терапевтичного профілю

\begin{tabular}{|c|c|}
\hline Фактор ризику & Бали \\
\hline Активний рак (метастази та/або хіміотерапія або радіотерапія впродовж останніх 6 місяців) & 3 \\
\hline ВТЕ в анамнезі (за винятком тромбозу поверхневих вен) & 3 \\
\hline Обмежена рухливість (ліжковий режим х3днів) & 3 \\
\hline $\begin{array}{l}\text { Відома тромбофілія (дефекти антитромбіну, протеїну C a6o S , фактора V Лейден, мутація протромбіну } \\
\text { G20210А, антифосфоліпідний синдром) }\end{array}$ & 3 \\
\hline Травма та/або операція $\leq 1$ місяць тому & 2 \\
\hline Вік понад 70 років & 1 \\
\hline Серцева та/або дихальна недостатність & 1 \\
\hline Гострий інфаркт міокарда або ішемічний інсульт & 1 \\
\hline Гостре інфекційне та/або ревматичне захворювання & 1 \\
\hline Ожиріння (IMT $\geq 30$ кг/M²) & 1 \\
\hline Застосування гормональної терапії & 1 \\
\hline Загальна оцінка факторів ризику (сума балів) & \\
\hline
\end{tabular}

Тромбофілія - це схильність до надмірного тромбоутворення внаслідок генетичних або набутих дефектів гемостазу, який $є$ результатом складної взаємодії формених елементів крові, факторів згортання та ендотелію судин. Як свідчать результати популяційних досліджень, поширеність тромбофілій у медичній практиці становить 15-20\% [1].

Класифікація тромбофілій наступна $[2,3]$ :

1) вроджені тромбофілії - резистентність активованого протеїну C, фактора V (Лейдена); дефіцит антитромбіну III, C або S (зниження рівня або активності); мутація гена протромбіну G20210A; поліморфізм гена інгібітора активатора плазміногену (PAl-1); деякі види дисфібриногенемії; гомозиготна форма гомоцистинурії (дефіциту цистатіонін- $\beta$-синтази), дефіцит плазміногену, підвищена активність фактора VIII, гіпергомоцистеїнемія (поліморфізм гена МTHFRC667T, мутації CSB).

2) набуті тромбофілії - антифосфоліпідний синдром (АФС); гіпергомоцистеїнемія (пов'язана з нирковою недостатністю, гіпотиреозом або лікуванням антагоністами фолатів, зокрема метотрексатом); підвищений рівень факторів VIII, IX, XI; набута резистентність до активованого протеїну C (вагітність, прийом пероральних контрацептивів); мієлопроліферативні захворювання; справжня поліцитемія; ідопатична тромбоцитемія.

3) комбіновані форми тромбофілії - поєднання кількох набутих і спадкових дефектів системи гемостазу, наявність люпус-антикоагулянта, антитіл до кардіоліпінів.

Порушення гемостазу та реологічних властивостей крові пов'язані з підвищеним ризиком ви- никнення венозних ВТЕ. Проте не всі види тромбофілії мають однаковий тромботичний ризик.

Класифікація тромбофілій за ризиком розвитку ВТЕ наступна [4]:

1) низький ризик - гетерозиготні форми мутації фактора V (Лейдена) і гена протромбіну 20210A; дефіцит протеїну C або протеїну S.

2) високий ризик - гомозиготні форми вищевказаних мутацій, комбінація гетерозиготних форм мутацій, дефіцит антитромбіну, АФС.

На жаль, у сучасних Європейських (2017) та вітчизняних (Українські міждисциплінарні клінічні рекомендації з профілактики, діагностики та лікування ВТE, 2017) не прописано чітких критеріїв, в яких випадках необхідно виключати у хворого тромбофілію. Найвагомішими критеріями, на нашу думку, щодо показань для обстеження на наявність спадкових дефектів гемостазу $\epsilon$ такі дані анамнезу: поява тромбозу у пацієнтів віком до 40 років, наявність в анамнезі не менше двох випадків тромбоемболії легеневої артерії (ТЕЛА) чи тромбозу глибоких вен (ТГВ) у кровних родичів першої лінії, ідіопатичний тромбоз, поєднання артеріального і венозного тромбозу, тромбоз незвичайної локалізації (вен головного мозку, брижі кишечника), рецидивуючий тромбофлебіт, утворення вогнищ некрозу внаслідок застосування кумаринів, повторний викидень, поєднання тромбозу із загибеллю плода, діти з геморагічною пурпурою, виникнення тромбозу під час ситуацій, що зазвичай легко переносяться (наприклад, застосування естрогенів, вагітність, тривалий переліт тощо) [3, 5].

Наводимо власне клінічне спостереження спадкової тромбофілії. 05.10.18 р. у палату інтен- 
Огляди літератури, оригінальні дослідення, погляд на проблему, ювілеї

сивної терапії кардіологічного відділення Тернопільської університетської лікарні (ТУл) госпіталізовано хворого Д. віком 23 років, зі скаргами на виражену загальну слабкість, задишку та ядуху, періодично сухий кашель. 3 анамнезу з'ясовано, що пацієнт у лютому 2017 року лікувався з приводу рентгенологічно і клінічно підтвердженої пневмонії. В зв'язку з наростанням задишки у квітні того ж року лікувався та обстежувався в кардіологічному відділенні ТУЛ, де було діагностовано ТЕЛА та тромбоз глибоких вен правої нижньої кінцівки. Після успішного медикаментозного лікування (в т.ч. тромболітичної та антикоагулянтної терапії) хворий самостійно звернувся в Інститут серця МОЗ України, де проведено тромбемболектомію із легеневих артерій, пластику трикуспідального клапана опорним кільцем, пластику вушка лівого передсердя. Післяопераційний період перебігав без особливостей, хворому рекомендували постійний прийом синкумару 2 мг 1 раз на добу під контролем коагулограми (результати коагулограми від 27.09.2018 р. - протромбіновий час 25,5 с, протромбіновий індекс 33,5 \%, міжнародне нормалізаційне відношення ((МНB) - 2,09), силденафілу 25 мг 3 рази на добу, спіронолактону 50 мг 1 раз на добу, небівололу 2,5 мг на добу. Погіршення загального стану від- мічає з серпня 2018 року, коли з'явились задишка при незначних фізичних навантаженнях, виражений акроціаноз, набряки на нижніх кінцівках, асцит.

При госпіталізації положення в ліжку вимушене, напівсидяче, шкірні покриви бліді, помірно вологі, теплі на дотик, виражений акроціаноз. Температура тіла від $36,6^{\circ} \mathrm{C}$. Пульс - 98 на хвилину, ритмічний. На кардіомоніторі синусовий ритм. Артеріальний тиск - 100/70 - 90/60 мм рт. ст. Аускультативно діяльність серця ритмічна, тони ослаблені, систолічний шум в т. Боткіна, акцент II тону над легеневою артерією. Дихання самостійне, адекватне. Частота дихання - 23/хвилину, сатурація кисню, за даними пульсоксиметрії, - 90 \% (на інгаляції зволоженим киснем). Над легенями вислуховується жорстке дихання, ослаблене в нижніх відділах легень, вологі хрипи справа. Язик вологий. Живіт симетричний, м'який. Печінка +6 см нижче реберної дуги. Помірний асцит. Болючість в косто-вертебральних синусах відсутня симетрично. Виражені периферійні набряки нижніх кінцівок.

Електрокардіограма (ЕКГ) при поступленні представлена на рисунку 1. Діагностовано синусову тахікардію з частотою серцевих скорочень близько 110 ударів за хвилину, синдром $\mathrm{S}_{1}-\mathrm{Q}_{3}$, ознаки неповної блокади правої ніжки пучка Гіса, блокади задньої гілки лівої ніжки пучка Гіса.
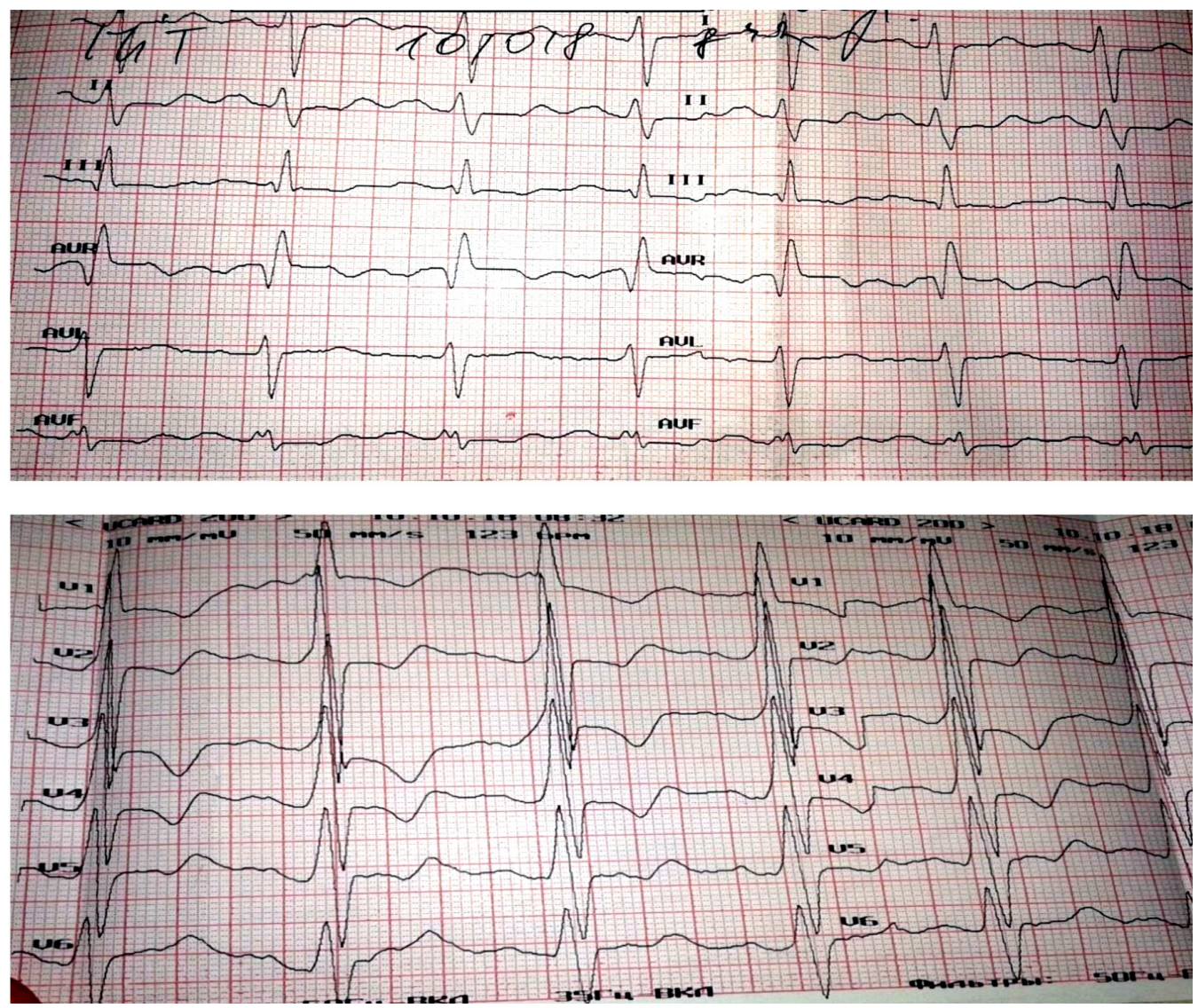

Рис. 1. ЕКГ пацієнта Д., 10.10.2018 р. 
Огляди літератури, оригінальні дослідення, погляд на проблему, ювілеї

Враховуючи показники гемодинаміки, стан пацієнта оцінений як тяжкий. Ймовірність ТЕЛА, згідно з шкалами Wells (4,5 бала) та Geneva (8 балів), була оцінена як середня [6].

За результатами біохімічного аналізу крові було відмічено незначне підвищення рівня МВфракції креатинфосфокінази (МВ-КФК) - 31,0 Од/л (норма < 25,0 Од/л). Інших відхилень лабораторних показників не виявлено.

Діагностичний пошук проводився згідно з алгоритмом, що представлений у клінічних рекомендаціях European Society of Cardiology (2014) щодо ведення пацієнтів з ТЕЛА [6]. Проведено визначення рівня D-димера - 5,23 нг/мл (норма <0,05-0,5 нг/мл). За даними ехокардіоскопії виявлено ознаки дилатації та перевантаження правих відділів серця (правий шлуночок розміром 4,0 см, праве передсердя - $26 \mathrm{~cm}^{2}$, о6'єм - $\left.98 \mathrm{~cm}^{3}\right)$, градієнт тиску на трикуспідальному клапані (ТК) - 71 мм рт. ст., систолічний тиск в легеневій артерії 86 мм рт. ст., в порожнині правого передсердя локується тромб 3,0×2,4 см, дещо неоднорідної ехоструктури та ехогенності; також у правому шлуночку з латерального боку кільця ТК більш ехогенний тромб 1,8×1,2 см, систолічна екскурсія кільця ТК (TAPSE) 11 мм, фракція викиду збережена (59 \%) (рис. 2).

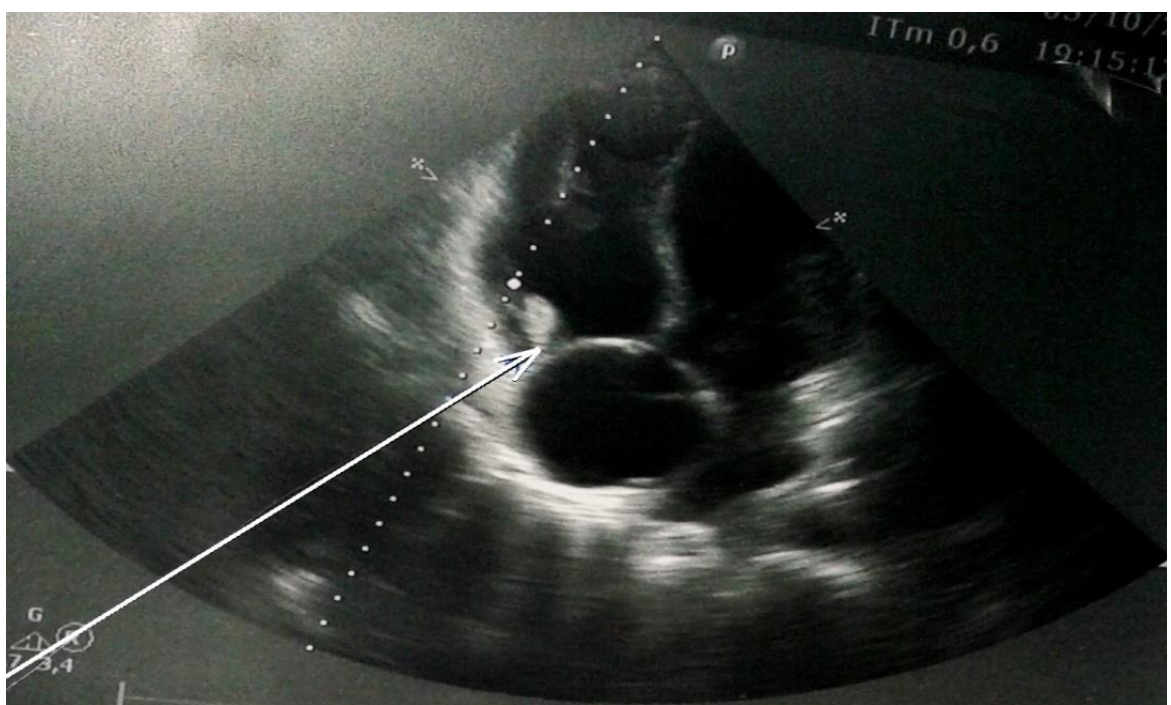

Рис. 2. Дані ЕхоКС пацієнта Д., 05.10.2018 р. (апікальна чотирикамерна позиція, стрілкою вказано тромб у правому шлуночку з латерального боку опорного кільця ТК).

Діагноз було підтверджено результатами комп'ютерної томографії легень з контрастуванням: двобічна тромбоемболія нижньочасткових легеневих артерій, верхньочасткової легеневої артерії справа, інфаркт-пневмонія S9, S10 справа, тромботичні маси правого передсердя та верхньої порожнистої вени (рис. 3).

Враховуючи клінічну картину захворювання, оцінку за шкалою PESI [7] - 113 балів, високий ризик (4,0-11,4 \%), результати інструментальних та лабораторних методів обстеження, у пацієнта було діагностовано ТЕЛА високого ризику.

Згідно з клінічними рекомендаціями Еuгоpean Society of Cardiology (2014) [6], враховуючи показники гемодинаміки (стійка артеріальна гіпотензія) та відсутність абсолютних та відносних протипоказань до тромболітичної терапії, проведено тромболізис альтеплазою 100 мг протягом 2 годин з наступною антикоагулянтною терапією гепарином 1000 Од на годину протягом 5 діб під контролем активованого часткового тромбопластинового часу (46-72 секунди), антибіотико- терапію, дезінтоксикаційну терапію, призначено дилтіазем 120 мг/добу, спіронолактон 50 мг/добу, силденафіл 120 мг/добу.

При компресійному дуплексному ультрасонографічному обстеженні судин обох кінцівок (7.10.2018) глибокі та поверхневі вени прохідні, тромбів не виявлено, компресія повна.

Оскільки не було виявлено чітких причинних факторів ризику для розвитку повторної ТЕЛА (на фоні постійної адекватної терапії непрямим антикоагулянтом проведено аналіз на тромбофілію: вовчаковий антикоагулянт - скринінговий тест 65,9 с (норма - 31,0-44,0), підтверджувальний тест - 44 с (норма 30,0-38,0), ПлР: ген F7 - мутація виявлена (гомозиготне носійство), ген F13A1 мутація виявлена (гетерозиготне носійство), ген серпін 1 - мутація виявлена (гомозиготне носійство). Отримані результати дозволили встановити діагноз вродженої тромбофілії, форма F7, F13A1, серпін 1. Даний тип тромбофілії передбачає довготривале лікування прямими антикоагулянтами. 
Огляди літератури, оригінальні дослідження, погляд на проблему, ювілеї
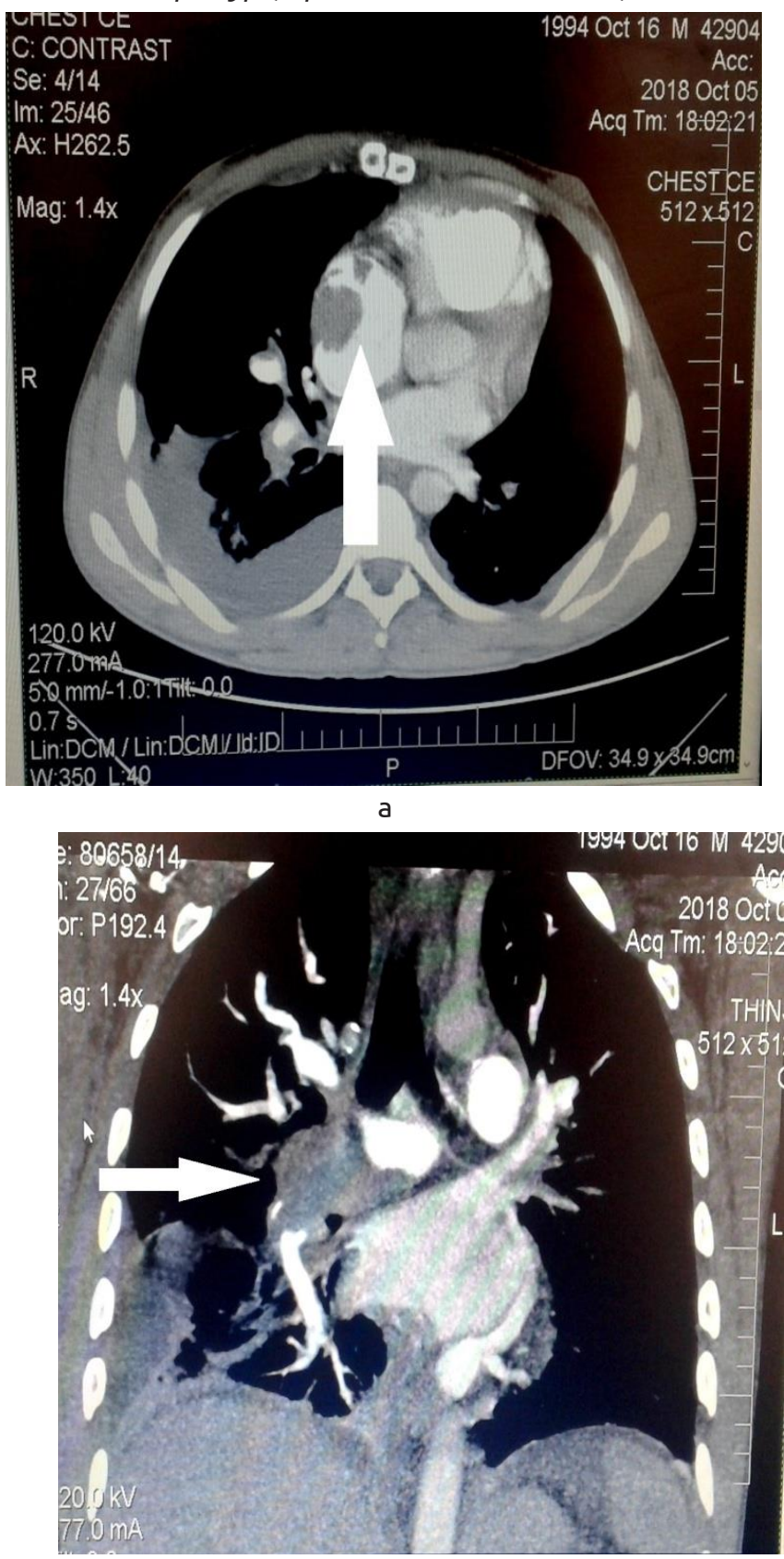

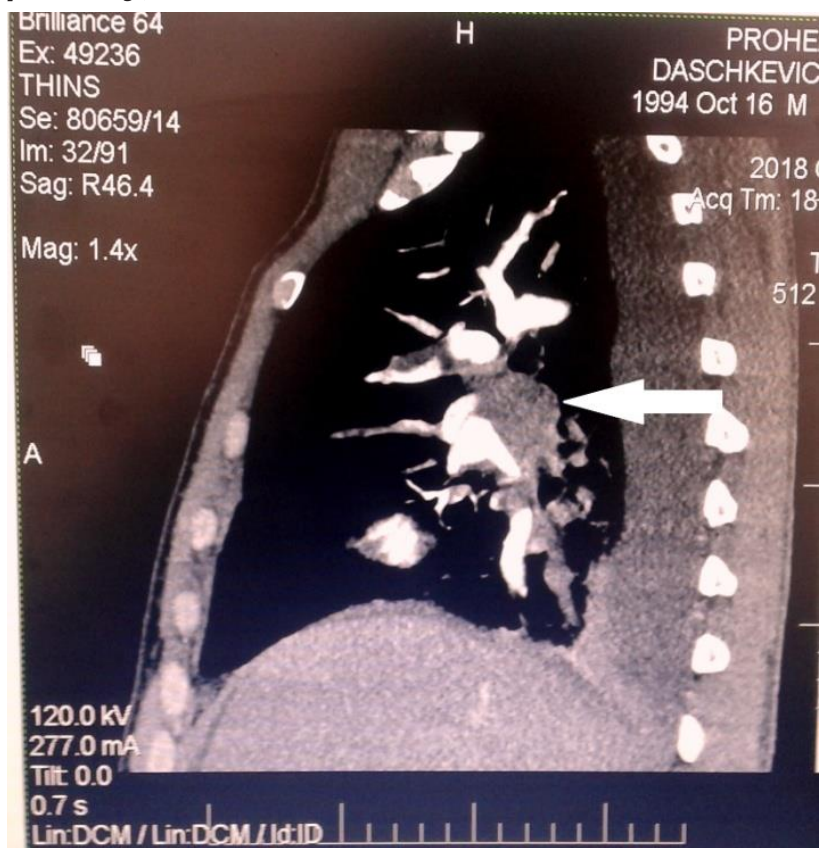

6

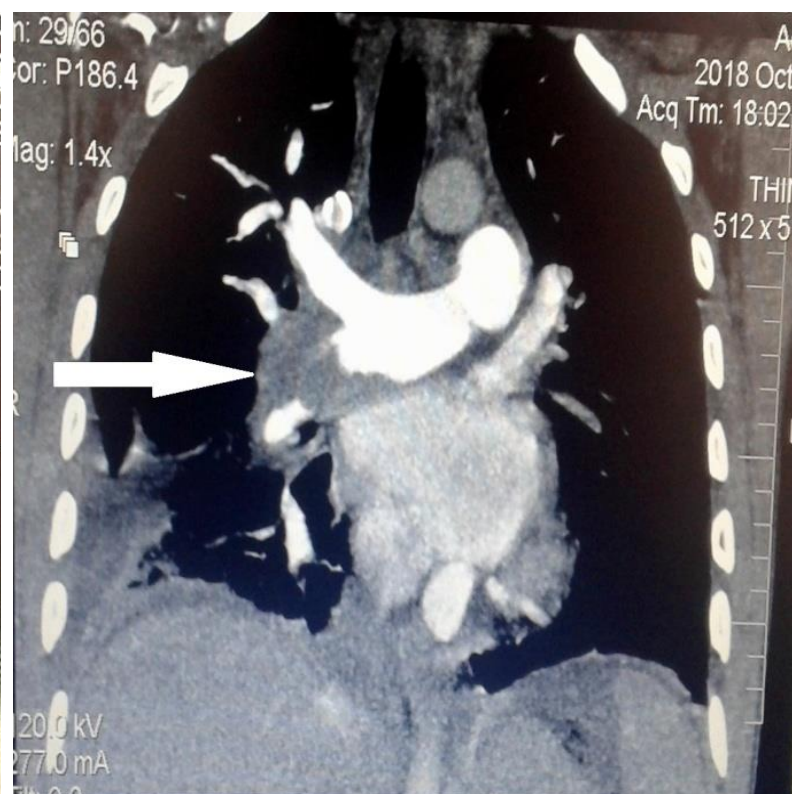

B

Рис. 3. Комп'ютерна томографія легень пацієнта Д., 05.10 .2018 р., стрілкою вказано пристінково-тромботичні маси розміром 30/32/28 мм у правому передсерді (а); стрілкою вказано пристінкові дефекти перфузії нижньочасткової легеневої артерії зліва (6); стрілкою вказано пристінкові дефекти перфузії нижньочасткової легеневої артерії з поширенням процесу на верхньочасткову легеневу артерію справа (в).

Враховуючи наявність у хворого особливого типу тромбофілії, при якому непрямі антикоагулянти (антагоністи вітаміну К) неефективні, пацієнт був переведений на пролонгований довготривалий (6-місячний) прийом еноксапарину в дозі 1 мг на кілограм маси тіла 2 рази на добу підшкірно під контролем АЧТЧ. Після проведеного комплексного лікування стан пацієнта покращився, зменшились частота та інтенсивність нападів задишки. Насичення артеріальної крові киснем при пульсоксиметрії зросло до 93 \% (без інгаляції киснем), стабілізувались показники центральної гемодинаміки (артеріальний тиск 115/75-120/80 мм рт. ст., ЧСС - 78-86/хв). Повторна ЕхоКС виявила зменшення градієнта тиску на трикуспідальному клапані до 40 мм рт. ст., зменшення розмірів правого передсердя до $23 \mathrm{~cm}^{2}$, зниження ступеня легеневої гіпертензії до 50 мм рт. ст.; в порожнині правого передсердя виявлено ехогенний округлий утвір $2 \times 6$ см, можливо кальцинований тромб. 
Огляди літератури, оригінальні дослідження, погляд на проблему, ювілеї

У результаті контрольної комп'ютерної томографії легень з контрастуванням судин (18.10.18р.) встановлено двобічну тромбоемболію нижньочасткових легеневих артерій, верхньочасткової легеневої артерії справа, інфаркт-пневмонію S9, S10 справа у фазі розрішення, пристінкові тромботичні маси правого передсердя.

Після покращення клінічного стану пацієнта та повної стабілізації гемодинаміки хворий повторно направлений у спеціалізоване кардіохірургічне відділення з метою проведення тромбемболектомії та узгодження пролонгованої медикаментозної профілактичної терапії з урахуванням неефективності пероральних антикоагулянтів (антагоністів вітаміну К) при даній формі тромбофілії.

Висновки. 1. Для оцінки ризику ВТЕ у госпіталізованих пацієнтів терапевтичного профілю доцільно використовувати шкалу Падуа, а при повторних ВТЕ/ТЕЛА, особливо у пацієнтів молодо- го віку, показане обов'язкове обстеження з метою підтвердження/виключення вродженої або набутої тромбофілії, що визначає програму профілактики повторних ВТЕ.

2. У хворих з діагностованою тромбофілією необхідно використовувати персоніфікований підхід до вибору антикоагулянтних засобів профілактики. Показання для застосування прямих чи непрямих антикоагулянтних засобів визначаються наявністю у пацієнта певної форми тромбофілії.

3. Велика частота захворюваності на ВТЕ, недостатні знання практикуючих лікарів щодо діагностики самої хвороби, визначення її причин і клінічних форм, а також неоднозначність отриманих результатів різних програм лікування і профілактикИ ВТЕ/ТЕЛА обґрунтовують необхідність проведення додаткових багатоцентрових клінічних досліджень та більш широкого обговорення даної проблеми в лікарському середовищі.

\section{ЛITEPATУPA}

1. Guidance for the evaluation and treatment of hereditary and acquired thrombophilia / Scott M. Stevens, Scott C. Woller, Kenneth A. Bauer [et al.] // J. Thromb. Thrombolysis. - 2016. - No. 41. - P. 154-164 DOI: 10.1007/ s11239-015-1316-1.

2. Salwa Khan. Hereditary thrombophilia / Salwa Khan, Joseph D. Dickerman // Thromb. J. - 2006. - No. 4. P. 15.doi:10.1186/1477-9560-4-15.

3. Коваленко В. М. Серцево-судинні захворювання. Рекомендації з діагностики, профілактики та лікування / В. М. Коваленко, М. І. Лутай. - 2011. - с. 375-376.

4. eMPendium - електронний компендіум «Внутрішні хвороби» у відкритому доступі [Електронний ресурс]. Режим доступу: https://empendium.com/ua/ chapter/B27.II.15.22.

\section{REFERENCES}

1. Scott M. Stevens, Scott C. Woller, \& Kenneth A. Bauer (2016). Guidance for the evaluation and treatment of hereditary and acquired thrombophilia. J. Thromb. Thrombolysis, 41, 154-164 DOI: 10.1007/s11239-015-1316-1.

2. Salwa Khan, \& Joseph D. Dickerman. (2006). Hereditary thrombophilia. Thromb. J., 4, 15. doi:10.1186/1477-9560-4-15.

3. Kovalenko, V.M., \& Lutai, M.I. (2011). Sertsevo-sudynni zahvoriuvannia. Rekomendatsii z diahnostyky, profilaktyky ta likuvannia [Cardiovascular disease. Recommendations for diagnosis, prevention and treatment]. Kyiv [in Ukrainian]

4. eMPendium - elektronyi compendium "Vnutrishni khvoroby" u vidkrytomu dostupi [eMPendium - e-Compendium "Internal Diseases" in open access]. Retrieved from:https:// empendium.com/ua/chapter/B27.II.15.22. [in Ukrainian].

5. Susan Murin, Gregory P. Marelich, \& Alejandro C. Arroliga (1998). Hereditary thrombophilia and venous
5. Hereditary thrombophilia and venous thromboembolism / Susan Murin, Gregory P. Marelich, Alejandro C. Arroliga [et al.] // American Journal of Respiratory and Critical Care Medicine. - 1998. - No. 158. https://doi. org/10.1164/ajrccm.158.5.9712022PubMed:9817680.

6. 2014 ESC guidelines on the diagnosis and management of acute pulmonary embolism / S. V. Konstantinides, A. Torbicki, G. Agnelli [et al.] // Eur. Heart J. - 2014. No. 35 (43). - P. 3033-3069.

7. MDApp - електронний компендіум медичних алгоритмів, калькуляторів у відкритому доступі. [Електронний ресурс]. Режим доступу: https://www.mdapp.co/pulmonary-embolism-severity-index-pesi-score-calculator-118/.

8. Пархоменко А. Н. Профилактика и лечение тромбозов: множество граней одной проблемы / А. Н. Пархоменко // Здоровье Украины. К. - 2017. - № 6. - С. 3-4.

thromboembolism. American Journal of Respiratory and Critical Care Medicine, 158. https://doi.org/10.1164/ajrccm. 158.5.9712022PubMed:9817680.

6. Konstantinides, S.V., Torbicki, A., \& Agnelli, G. (2014). ESC guidelines on the diagnosis and management of acute pulmonary embolism. Eur. Heart J., 35 (43), 3033-3069.

7. MDApp - elektronyi compendium medychnyh algorytmiv, kalkulyatoriv u u vidkrytomu dostupi [MDApp is an electronic compendium of medical algorithms, open source calculators]. Retrieved from: https://www.mdapp. co/pulmonary-embolism-severity-index-pesi-scorecalculator-118/ [in Ukrainian]

8. Parkhomenko, A.N. (2017). Profilaktika i lecheniya trombozov: mnozhestvo graney odnoy problem [Thrombosis prevention and treatment: many facets of one problem]. Zdorove Ukrainy. K. - Health of Ukraine. K., 6, 3-4 [in Russian]. 


\title{
ТРОМБОФИЛИЯ, ОСЛОЖНЕННАЯ РЕЦИДИВИРУЮЩЕЙ ТРОМБОЭМБОЛИЕЙ ЛЕГОЧНОЙ АРТЕРИИ - КЛИНИЧЕСКИЙ СЛУЧАЙ С АНАЛИЗОМ СОВРЕМЕННЫХ ДИАГНОСТИЧЕСКИХ И ЛЕЧЕБНЫХ АЛГОРИТМОВ ВЕДЕНИЯ БОЛЬНЫХ
}

\author{
๑М. И. Швед, Н. М. Ковбаса, С. М. Геряк, С. И. Липовецка,
} Л. В. Левицка, О. А. Прокопович, О. Л. Сидоренко

\author{
ДВНЗ «Тернопольский государственный медицинский университет имени И. Я. Горбачевского \\ МОЗ Украины»
}

РЕЗЮМЕ. Венозный тромбоз и эмболия (ВТЭ) - одно из самых тяжелых по течению и угрожающих для жизни осложнений.

Цель исследования - проанализировать современные подходы к диагностике и лечению больных с тромбофилией, осложненной рецидивирующей тромбоэмболией легочной артерии на основе собственного клинического случая.

Результаты. Для оценки риска ВТЭ у госпитализированных пациентов терапевтического профиля целесообразно использовать шкалу Падуа, а при повторных ВТЭ / ТЭЛА, особенно у пациентов молодого возраста, показано обязательное обследование с целью подтверждения / исключения врожденной или приобретенной тромбофилии, что определяет программу профилактики повторных ВТЭ. У больных с диагностированной тромбофилией необходимо использовать персонифицированный подход по выбору антикоагулянтных средств профилактики. Показания для использования прямых или непрямых антикоагулянтов определяется наличием у пациента определенной формы тромбофилии. Только использование такого диагностического алгоритма позволяет своевременно назначить адекватную профилактическую антикоагулянтную терапию таким пациентам, что подтверждает описанный нами клинический случай.

Выводы. Большая частота заболеваемости ВТЭ, недостаточные знания практикующих врачей по диагностике самой болезни, определение ее причин и клинических форм, а также неоднозначность полученных результатов различных программ лечения и профилактики ВТЭ/ТЭЛА обосновывают необходимость проведения дополнительных многоцентровых клинических исследований и более широкого обсуждения данной проблемы среди врачей.

КЛЮЧЕВЫЕ СЛОВА: тромбоэмболия легочной артерии; тромбофилия; диагностика; лечение.

\section{THROMBOPHILIA, COMPLICATED BY RECURRENT PULMONARY THROMBOEMBOLISM - CLINICAL CASE WITH ANALYSIS OF MODERN DIAGNOSTIC AND TREATMENT ALGORITHMS

\author{
@M. I. Shved, N. M. Kovbasa, S. M. Geryak, S. Y. Lypovetska, L. V. Levytska,
} \\ O. A. Prokopovich, O. L. Sydorenko \\ I. Horbachevsky Ternopil State Medical University}

SUMMARY. Venous thrombosis or embolism (VTE) is one of the most severe life-threatening complications.

The aim of the study - to analyze modern approaches to diagnosis and treatment of patients with thrombophilia complicated by recurrent pulmonary thromboembolism on the basis of own clinical case.

Results. For evaluation of VTE risk the Padua scale is recommended, especially in young patients. A compulsory screening to confirm or rule out the congenital or acquired thrombophilia that determines the program for the prevention of recurrent VTE should be performed. In patients with diagnosed thrombophilia it is necessary to use a personified choice of anticoagulants. Indications for the use of direct or indirect anticoagulants are determined by specific forms of thrombophilia. This diagnostic algorithm allows prescribing adequate preventive anticoagulant therapy in such patients, which was confirmed in our clinical case.

Conclusions. The high incidence of VTE, lack of knowledge among practitioners regarding the diagnosis of the disease, identification of its causes and clinical forms, and the ambiguity of results of various programs of treatment and prevention of VTE, substantiate the need for additional multicenter clinical trials and a broader discussion of this problem among medical society.

KEY WORDS: pulmonary thromboembolism; thrombophilia; diagnostics; treatment. 